\title{
Physico-Chemical and Bacteriological Quality of the Vegetable Watering Water in the Dschang Town, Cameroon
}

\author{
Ntangmo Tsafack Honorine ${ }^{1 *}$, Temgoua Emile ${ }^{2}$, Njine Thomas ${ }^{3}$ \\ ${ }^{1}$ Laboratory of Applied Biology and Ecology, Department of Animal Biology, Faculty of Sciences, University of Dschang, Dschang, \\ Cameroon; ${ }^{2}$ Laboratory of Soil Analysis and Environment Chemistry, Department of Soil Sciences, Faculty of Agronomy and Agri- \\ cultural Sciences, University of Dschang, Dschang, Cameroon; ${ }^{3}$ Laboratory of General Biology, Department of Animal Biology and \\ Physiology, Faculty of Sciences, University of Yaoundé I, Yaoundé, Cameroon. \\ Email: emile.temgoua@univ-dschang.com,njinet@yahoo.fr, ${ }^{*}$ tsafackhonorine@yahoo.fr
}

Received June $4^{\text {th }}, 2012$; revised July $3^{\text {rd }}, 2012$; accepted August $1^{\text {st }}, 2012$

\begin{abstract}
Market gardening, in the swampy lowlands of the Dschang city, plays an important role in terms of providing employment, and supply the city with fresh products. However, waterborne diseases, which occur in the city, are both attributed to the bad quality of drinking water and sanitation practices. This work aims to characterize watering waters of crop, to assess the health risks associated with the use of these waters. Water from eleven streams and five wells used to irrigate crops were sampled and analyzed once a week for a month. Analyses focused on physico-chemical parameters (temperature, suspended matter, $\mathrm{pH}$, electrical conductivity, $\mathrm{COD}, \mathrm{BOD}_{5}, \mathrm{NO}_{3}^{-}, \mathrm{Al}, \mathrm{Fe}, \mathrm{Cu}, \mathrm{Ni}$ ), parasitological (helminthes eggs) and bacteriological (total coliforms, fecal coliforms, fecal streptococcus). The results show that, the physico-chemical quality of well waters generally approaches the WHO standards of crop watering water. The physico-chemical of streams waters and bacteriological quality of wells and streams waters are bad, according to WHO guide. These bad quality waters could contaminate crops, some of which are eaten raw, which is surely a cause of the outbreak of waterborne diseases in the city. The waters from streams are more affected. The pretreatment of the water before use for irrigation of vegetables is highly recommended.
\end{abstract}

Keywords: Watering Water Quality; Urban Market Gardening; Sanitary Risks

\section{Introduction}

Dschang is an university town with rapid demographic growth. This town covers a surface area of more than 1300 hectares, with an estimated population of about 109,556 in habitants [1]. There are many swampy areas in this town which are valorized by the poor for dwelling in one hand and for market gardening in the other hand $[2,3]$. More than 10 hectares of land are cultivated in these swamps. The most highly produced vegetable include; huckle berry, tomatoes, celery, green pepper, basil, parsley, garden eggs (African aubergine), cabbage, lettuce, green-beans, leeks and carrots. About $96 \%$ of these plants are grown by watering while $4 \%$ are irrigated in the dry season. This market gardening activity is in rapid expansion within this town, and plays a vital role in the supply of the town with cheap and fresh products. This activity also provides employment for many families

*Corresponding author. generally living under conditions of extreme poverty.

However, the water used for watering of these crops even those likely to be consumed raw is of doubtful qualities, where these harvest crops are sold directly to the city dwellers. The town does not have any wastewater treatment unit, so the streams receive all sorts of wastewaters originating from the city. According to an investigation carried in Dschang, about $10 \%$ of water used for watering comes from wells and $90 \%$ from untreated water of streams. Some latrines and septic tanks located along these streams are designed in a manner that their contents are emptied directly into these streams. During the rainy season, the water table rises causing floods on the cultivable lands and affecting the physical environment of wells. However, pathogenic microorganisms and chemical compounds present in the flooded waters used for watering can be a source of chemical and micro-biological contamination of the crops, and consequently harmful to the health of the consumers [4]. The 
potential risks of using untreated wastewater for agriculture were already highlighted [5-7]. Cholera, typhoid fever and paratyphoid epidemics already observed in Dakar and Kampala for example are allotted to the bad quality of water used in watering of crops [8]. The diagnosis made by UN-habitat [9]) and Boon [10] in Dschang proofed some cases of typhoid fever, intestinal parasites and diarrhea as recurrent diseases in the city $(19 \%$ of 8000 patients listed in 2008). An increasing accusing finger is being pointer to the source of water used in watering vegetables. In addition to poor quality of drinking water, these diseases can also originate from improper hygiene and, consumption of fresh food products soiled by pathogenic micro-organisms. The quality of some water points intended for human consumption in Dschang town is well known [10-13]. Unfortunately, no data is available in regard to the composition and quality of water used in watering the crops. This study is aimed to fill this gap. It is based on the evaluation of sanitary risks related to the use of watering water, provision of helpful elements for decision making so as to ensure a market gardening without risk in Dschang town.

\section{Materials and Methods}

\subsection{Water Collection Points}

Figure 1 presents the localization of Dschang town in West Cameroun. It also presents the principal sampling points (D). In all, 16 water points used for watering of crops, 5 wells and 11 streams were selected on 10 principal market gardening sites of the town (Fiala-Foto, Tapalé, Tsinkop, Tsenfem, Ngui, Minghong, Tchoualé, Vallée, Administratif, Fiala-Foréké).

\subsection{Water Collection and Analysis}

The water of each point was collected once a week throughout the month of February, that is mid dry season. This month corresponds to the period where there is high watering of crops.

The $\mathrm{pH}$, electrical conductivity (EC), and the temperature $\left(\mathrm{T}^{\circ} \mathrm{C}\right)$ of each sample were measured in situ; the $\mathrm{pH}$ was taken with the aid of portable pH-meter VARIO of VWR; electrical conductivity and temperature were done with the use of a conducting meter WTW LF 318 . The suspended matter (SM) was obtained after filtration and reading was done with the aid of a spectrophotometer. To quantify heavy metal and evaluate proportions of major elements $\left(\mathrm{NO}_{3}, \mathrm{Al}, \mathrm{Ni}, \mathrm{Fe}, \mathrm{Cu}\right)$, one made used of a Reflectometer RQ flex Plus 10 of Merk trade mark, using strips. The determination of chemical oxygen demand (COD) was done by colorimetry, this method combined digestion of organic matter at $150^{\circ} \mathrm{C}$ in a COD engine and the readings were done with a DR 2500-Hach spec- trophotometer. $\mathrm{BOD}_{5}$ was measured using the respirometric method by means of a BOD Track TM hach analyzer.

Biological indicators of fecal contamination and presence of helminthes eggs were retained from the study. The Mac Conkey medium was used for the identification of the fecal coliforms; the Bile Esculine medium for the identification of fecal streptococcus and, Agar Lactose with TTC and Tergitol 7 medium for the isolation and identification of total coliforms. Bacteriological analysis was done using the filter membrane technique. Helminthes eggs were detected under the optical microscope using an identification board. After having filtered two liters of a sample through a $0.45 \mu \mathrm{m}$ filter; the filter was rinsed in $10 \mathrm{ml}$ with distilled water, then a $\mu \mathrm{l}$ was built on the plate/slide and observe under the microscope at $40 \times$ magnification. Counting was not done.

\subsection{Data Analyses}

Adopted statistical methods used in the treatment of obtained results were based on simple descriptive statistical analyses. Variance analysis (ANOVA) was used to compare means. These means were compared using the smallest significance difference method (5\%). Calculations were carried out with the use of SPSS 10 for Windows and Excel.

\section{Results and Discussion}

\subsection{Physico-Chemical Quality of Watering Waters}

Tables 1 and 2 present the values of physico-chemical variables of water from streams and wells respectively at various collecting points. Still in Table 1, one sees some directives of physico-chemical quality.

Cameroon does not have directive on composition of water used in watering crops. The temperature of the streams significantly varies from one stream to another $(\mathrm{p}<0.01)$. It varies between $21.3^{\circ} \mathrm{C}$ and $24.3^{\circ} \mathrm{C}$ in stream and between $20.5^{\circ} \mathrm{C}$ and $22.8^{\circ} \mathrm{C}$ in the wells. Collected data in the entirety of analyzed samples had a temperature of less than $35^{\circ} \mathrm{C}$, which is considered as an indicative limiting value for water set aside for the watering of crops $[15,16]$.

The $\mathrm{pH}$ of water from streams is almost neutral or slightly acidic. $\mathrm{pH}$ range is common to several surface waters used for irrigation in Africa [16-18]. On the other hand, well water has an acidic $\mathrm{pH}$, this inappropriate for watering of crops and irrigation. Electrical conductivity varies from one water point to the other $(\mathrm{p}<0.01)$, either between a stream and well. Stream water presents an electrical conductivity between 44 and $209 \mu \mathrm{S} / \mathrm{cm}$, whereas that of wells has an electrical conductivity varying 

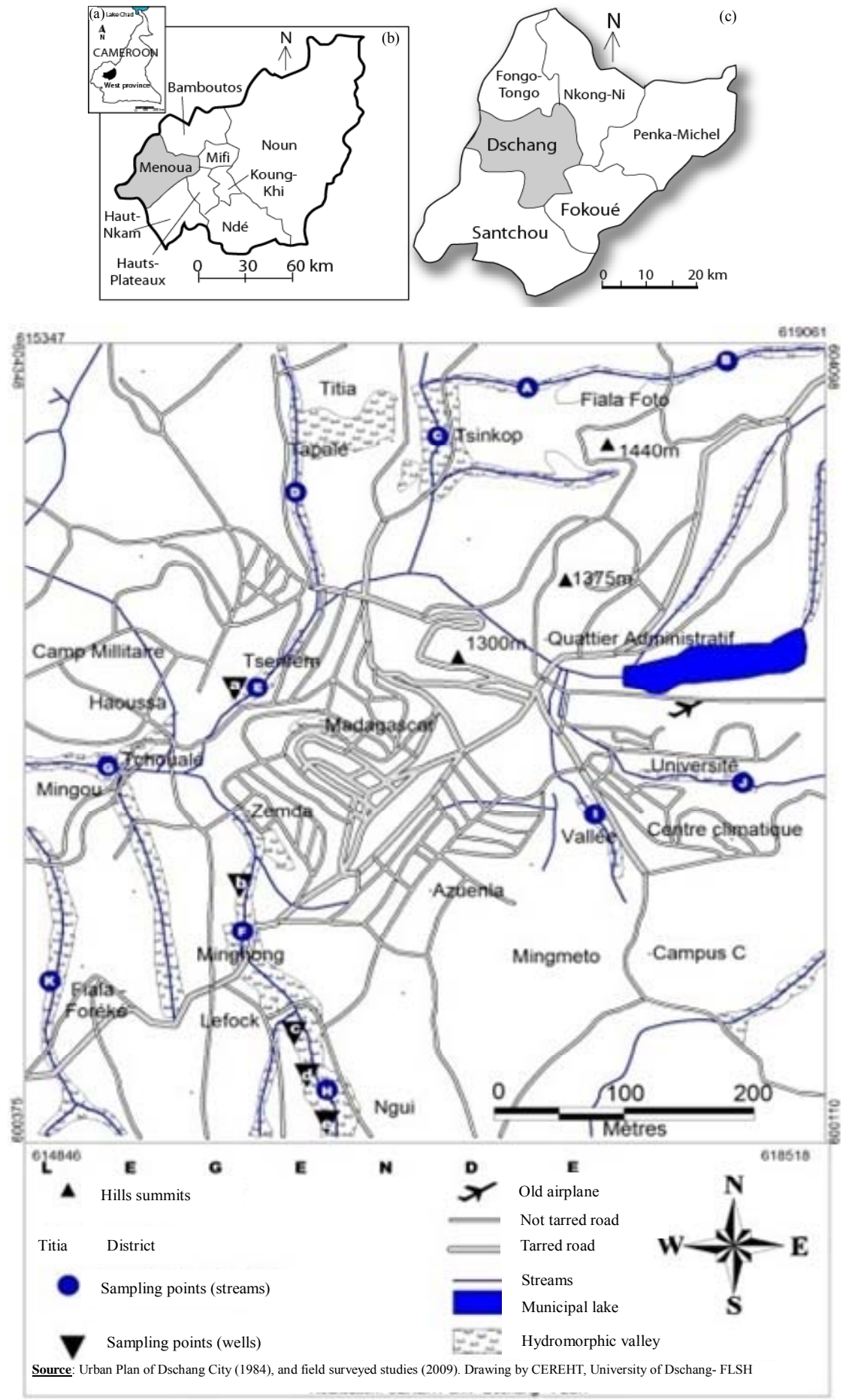

(d)

Figure 1. Localization of the town of Dschang in the department of Menoua (c), area of the West (b), in Cameroun (a). The chart (d) materializes the points of water sampling in the Dschang town.

between 95 and $346 \mu \mathrm{S} / \mathrm{cm}$. These values fulfill the requirements of good irrigation water quality [19]. The low values of electrical conductivity show that this water is slightly mineralized and cannot in an adequate way play the role of fertilizer as sought by their use.
The quantities of suspended materials present in Tsinkop, Tapalé, Minghong, Vallée and Tchoualé streams do not fulfill the norms of water destined for irrigation. The presence of enormous quantities of suspended materials from these streams leads to soil pores blockage thus 
Table 1. Values of the physico-chemical variables of stream water at the various intake points (average \pm standard deviation).

\begin{tabular}{|c|c|c|c|c|c|c|c|c|c|c|c|c|}
\hline $\begin{array}{c}\text { Site of taking } \\
\text { a way }\end{array}$ & $\begin{array}{c}\text { FialaFoto } \\
\text { b (A) }\end{array}$ & $\begin{array}{c}\text { Fiala Foto } \\
\mathrm{c}(\mathrm{B})\end{array}$ & $\begin{array}{l}\text { Tsinkop } \\
\text { (C) }\end{array}$ & $\begin{array}{l}\text { Tapalé } \\
\text { (D) }\end{array}$ & $\begin{array}{l}\text { Tsinfem } \\
(\mathrm{E})\end{array}$ & $\begin{array}{l}\text { Minghong } \\
\text { (F) }\end{array}$ & $\begin{array}{l}\text { Tchoualé } \\
\text { (G) }\end{array}$ & Ngui (H) & Vallée (I) & $\begin{array}{l}\text { Adminis } \\
\text { tratif }(J)\end{array}$ & $\begin{array}{c}\text { FialaForéké } \\
(\mathrm{K})\end{array}$ & $\begin{array}{c}\text { Standards } \\
{[14,15]} \\
\end{array}$ \\
\hline $\begin{array}{c}\text { Temperature } \\
\left({ }^{\circ} \mathrm{C}\right)\end{array}$ & $22.9 \pm 1.8$ & $21.3 \pm 2.2$ & $22.4 \pm 1.6$ & $21.9 \pm 1.6$ & $21.8 \pm 1.3$ & $21.7 \pm 1.9$ & $21.7 \pm 1.6$ & $22.2 \pm 1.7$ & $22.3 \pm 1.4$ & $24.3 \pm 1.5$ & $21.9 \pm 1.9$ & $<35$ \\
\hline $\mathrm{CE}(\mu \mathrm{S} / \mathrm{cm})$ & $59.9 \pm 13.7$ & $743.9 \pm 4.9$ & $59.4 \pm 4.95$ & $55.12 \pm 2.2$ & $59.5 \pm 1.7$ & $64.9 \pm 5.1$ & $73.2 \pm 4.5$ & $209.4 \pm 12.4$ & $109.8 \pm 33$ & $56 \pm 4.5$ & $61.6 \pm 7.1$ & $<7000$ \\
\hline $\mathrm{pH}$ & $7 \pm 0.4$ & $7 \pm 0.3$ & $6.8 \pm 0.2$ & $6.5 \pm 0.9$ & $6.5 \pm 1.2$ & $6.3 \pm 0.3$ & $6.2 \pm 0.3$ & $6.53 \pm 0.3$ & $6.3 \pm 0.2$ & $6.5 \pm 0.2$ & $6.6 \pm 0.5$ & $6.5-8.5$ \\
\hline $\mathrm{SM}(\mathrm{mg} / \mathrm{l})$ & $23.4 \pm 2$ & $5.5 \pm 5.1$ & $55.4 \pm 10.8$ & $43 \pm 2.1$ & $27 \pm 2.5$ & $66.2 \pm 24.5$ & $72 \pm 9.43$ & $8.3 \pm 3$ & $83.2 \pm 6.1$ & $12.2 \pm 4.3$ & $14.5 \pm 1.4$ & $<30$ \\
\hline $\mathrm{COD}(\mathrm{mg} / \mathrm{l})$ & $38 \pm 9.6$ & $42.2 \pm 7.6$ & $5515 \pm 20.8$ & $136 \pm 26.6$ & $37.4 \pm 8.3$ & $45.4 \pm 14$ & $50 \pm 14.6$ & $14.8 \pm 6$ & $60.6 \pm 12.7$ & $59.9 \pm 15.5$ & $45.4 \pm 20.8$ & $<90$ \\
\hline $\mathrm{BOD}_{5}(\mathrm{mg} / \mathrm{l})$ & $25 \pm 6.5$ & $28 \pm 10$ & $134 \pm 28.5$ & $90 \pm 36.6$ & $35 \pm 7.7$ & $31 \pm 13$ & $33 \pm 6.5$ & $9.8 \pm 4$ & $40 \pm 16.7$ & $39 \pm 9.8$ & $33 \pm 13$ & $<30$ \\
\hline $\mathrm{NO}_{3}^{-}(\mathrm{mg} / \mathrm{l})$ & $6 \pm 3.9$ & $27 \pm 8.9$ & $20 \pm 10.2$ & $5 \pm 1.25$ & $4 \pm 2.9$ & $4 \pm 2.21$ & $4 \pm 1.7$ & $25 \pm 5.7$ & $18 \pm 7.7$ & $9 \pm 4.5$ & $15 \pm 6.1$ & $<50$ \\
\hline $\mathrm{Cu}(\max )$ & $<5$ & $<5$ & $<5$ & $<5$ & 16 & $<5$ & $<5$ & $<5$ & $<5$ & $<5$ & $<5$ & $<0.5$ \\
\hline $\mathrm{Ni}(\max )$ & 22 & $<5$ & $<5$ & $<5$ & $<5$ & $<5$ & $<5$ & $<5$ & $<5$ & $<5$ & $<5$ & $<0.2$ \\
\hline
\end{tabular}

Table 2. Values of the physico-chemical variables of water of the wells (average \pm standard deviation).

\begin{tabular}{cccccc}
\hline Sites de prélèvements & Tsenfem (a) & Minghong (b) & Ngui p1 (c) & Ngui p2 (d) & Ngui p3 (e) \\
\hline Température $\left({ }^{\circ} \mathrm{C}\right)$ & $22.8 \pm 1.27$ & $20.5 \pm 0.8$ & $22.7 \pm 1$ & $22.4 \pm 1.3$ & $22.3 \pm 1.4$ \\
$\mathrm{CE}(\mu \mathrm{S} / \mathrm{cm})$ & $324.6 \pm 10.9$ & $94.6 \pm 8$ & $257 \pm 6.9$ & $342.3 \pm 21.8$ & $346.1 \pm 29$ \\
$\mathrm{pH}$ & $5 \pm 0.9$ & $5.6 \pm 0.3$ & $5.6 \pm 0.05$ & $5.5 \pm 0.1$ & $5.6 \pm 0.08$ \\
$\mathrm{MES}(\mathrm{mg} / \mathrm{l})$ & $4.2 \pm 7.7$ & $6.8 \pm 4.7$ & $0.6 \pm 0.9$ & $1 \pm 1.5$ & $5 \pm 3$ \\
$\mathrm{COD}(\mathrm{mg} / \mathrm{l})$ & $42.4 \pm 25.5$ & $68.7 \pm 20.8$ & $17.8 \pm 3.9$ & $16.9 \pm 5.3$ & $16.3 \pm 7.2$ \\
$\mathrm{BOD}_{5}(\mathrm{mg} / \mathrm{l})$ & $28 \pm 20.18$ & $45 \pm 16.8$ & $11.8 \pm 3.8$ & $11.2 \pm 4.8$ & $10.8 \pm 4.4$ \\
$\mathrm{NO}_{3}^{-}(\mathrm{mg} / \mathrm{l})$ & $76 \pm 22$ & $28 \pm 6.5$ & $74 \pm 11.4$ & $70 \pm 12.6$ & $70 \pm 29.8$ \\
\hline
\end{tabular}

preventing the normal respiration crops.

The $\mathrm{COD}$ and $\mathrm{BOD}_{5}$ of wells and streams vary widely from one sampling point to another $(p<0.01)$. The obtained $\mathrm{COD}$ and $\mathrm{BOD}_{5}$ values show that there is high pollution of water by organic compounds. $\mathrm{BOD}_{5}$ attained $134 \mathrm{mg} / \mathrm{l}$ in Tsinkop stream and $45 \mathrm{mg} / \mathrm{l}$ in Minghong wells. Apart from the Ngui, Fiala b and Fiala c streams, all the other streams have $\mathrm{BOD}_{5}$ values that do not fulfill the norms set aside for water quality destined for watering of crops. For the stream of Tsinkop and Tapalé, the contents of COD are higher than the threshold limit of 90 $\mathrm{mg} / \mathrm{l}$. On the other hand, all wells have a suitable COD for the watering of crops. But for irrigation water, the high concentration of organic matter constitutes a significant contribution of soil structuring elements dur- ing irrigation. Suspended matter, $\mathrm{BOD}_{5}$ and electrical conductivity of water samples are higher than the stan- dards, but remain lower than the values recorded in sev- eral effluents used for irrigation in Sebou and Meknes basins of Morocco and of Dakar in Senegal [7,16-18].

In all analyzed water samples, nitrate content present very significant differences $(p<0.01)$ between the up- shifted points. Wells present high nitrate concentration reaching $76 \mathrm{mg} / \mathrm{l}$. These nitrates originate from massive use of nitrogenous fertilizers which is a reality in this location [12,13]. All the streams have suitable nitrates content for irrigation. Most heavy metals content were below detection limit. Apart Tsenfem and Fiala b streams, we noticed that $\mathrm{Ni}$ and $\mathrm{Cu}$ had no acceptable contents. Conclusively, in the physico-chemical field, well waters although not respecting the standard norms is more favorable for watering of crops than water from streams.

\subsection{Bacteriological Quality of Water for Watering}

Abundances of the total coliforms in the wells vary between $10^{8}$ and $5 \times 10^{8} \mathrm{UFC} / 100 \mathrm{ml}$, those of the fecal coliforms between $9.2 \times 10^{5}$ and $3.2 \times 10^{6} \mathrm{UFC} / 100 \mathrm{ml}$, and those of fecal streptococcus between $6.8 \times 10^{6}$ and $1.4 \times 10^{7}$ UFC/100ml (Figure 2). Well water proves to be less polluted than stream waters in the bacteriological plan. For all the types of bacteria, this difference is significant $(p<0.05)$. The presence of ascaris eggs was detected in all the streams and well of Tsenfem. The micro- 
biological follow-up of watering water of the Dschang town shows that all the water used for crops watering in this city has bacterial load which highly exceeds by far the limits fixed by WHO for the irrigation. The presence of the biological indicators of fecal contamination translates a high probability of simultaneous presence of the pathogenic germs of fecal origin [20].

WHO fixes at $1000 \mathrm{UFC} / 100 \mathrm{ml}$ the quantity of bacteria (total coliforms, fecal coliforms and fecal streptococcus) acceptable for water intended for irrigation, and less

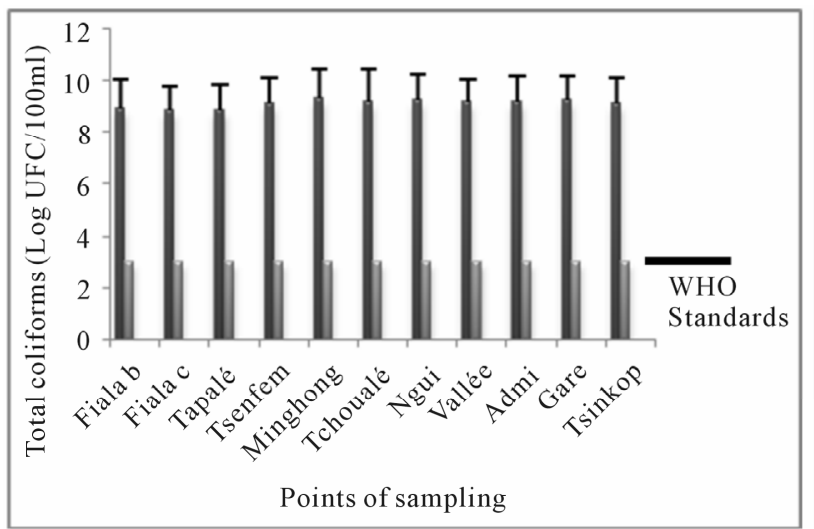

(a)

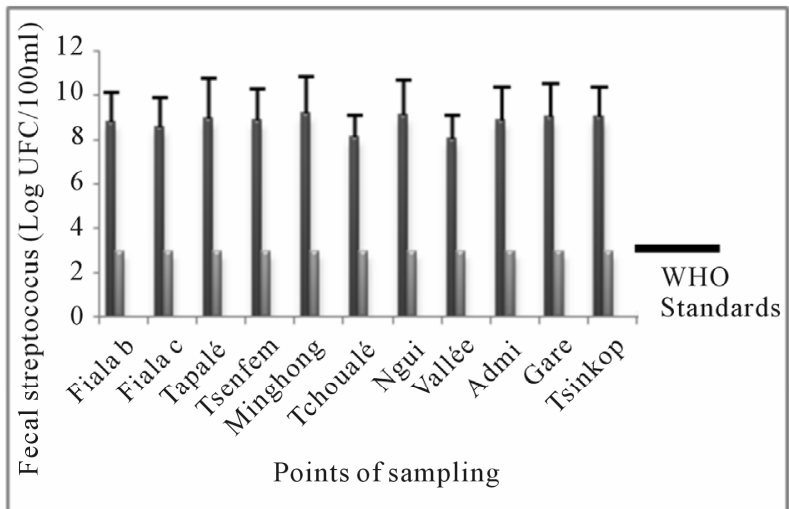

(c)

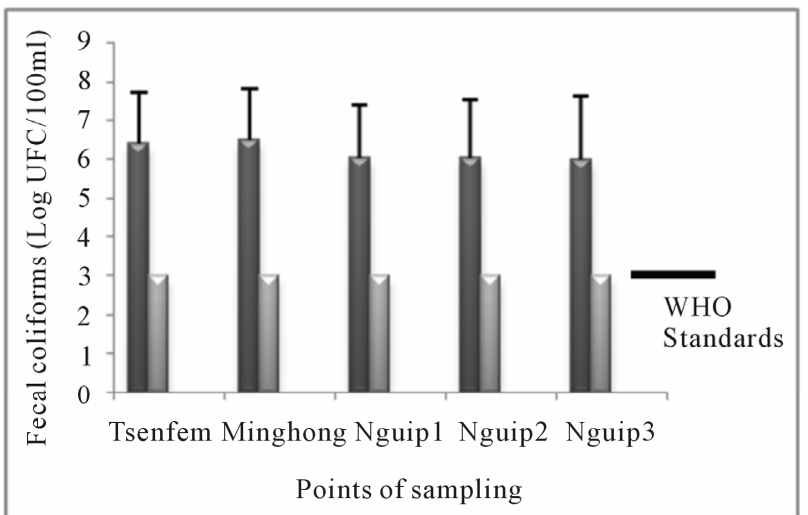

(e) than one egg of helminthes/liter [19]. Abundances of the total coliforms, fecal coliforms, and fecal streptococcus, in well water, are 900 to 500,000 times higher than the standard. In the stream, these abundances are 4500 to 2,200,000 times higher than the standards. This high bacteriological load in watering water of the town of Dschang leads us to question on the cases of typhoid, intestinal parasites and diarrhea, recurring in this city. Indeed, the diagnosis of UN-Habitat [9] and work of Boon [10] in Dschang proved these diseases as the recurring

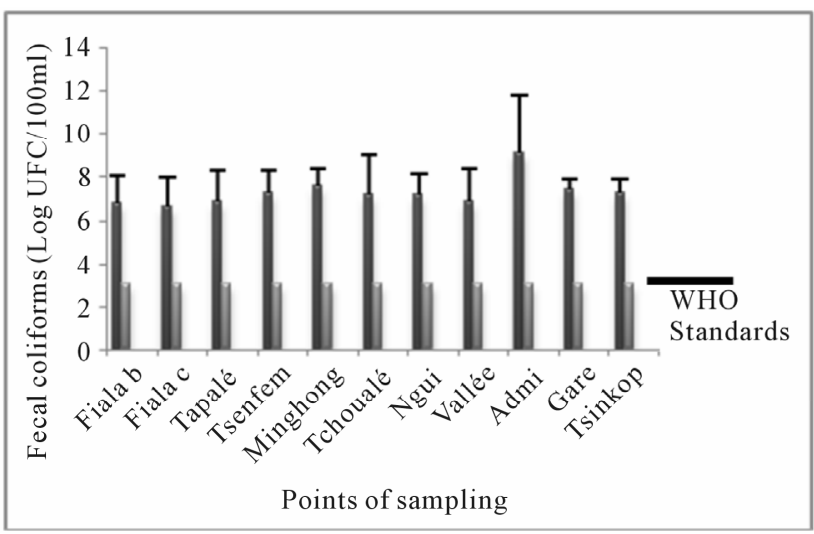

(b)

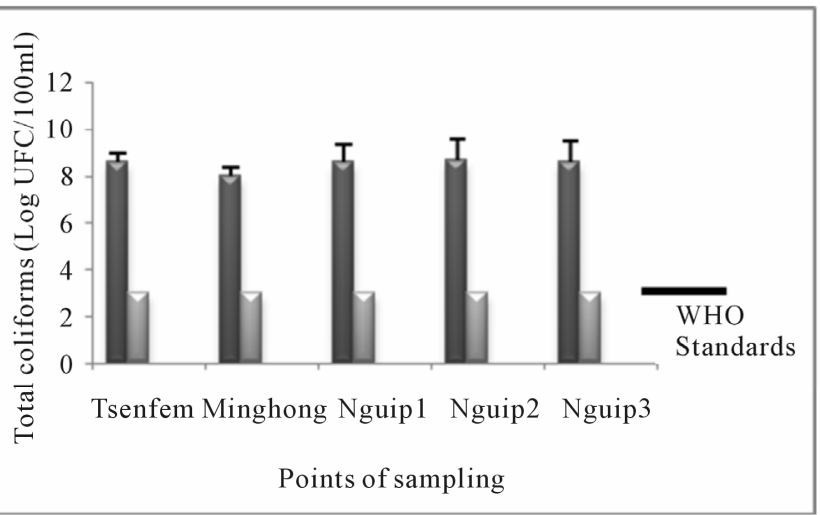

(d)

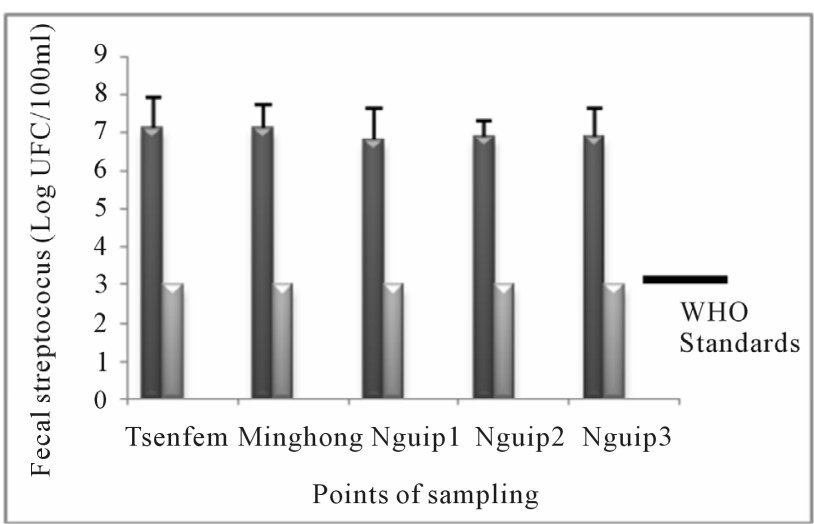

(f)

Figure 2. Abundances of the fecal bacteria from used stream (a, b, c) and well (d, e, f) waters for vegetable watering in Dschang. 
diseases in the city. These values are of the same order of magnitude as those generally found in the effluents and wells water used for the irrigation in Ghana, Senegal, Morocco, Benin, and Kenya [6,16-18,21]. But the bacterial load of watering water in Dschang are slightly weaker; this could be due to the fact that Dschang is a small city; the indicating bacteria of fecal contamination present in watering water come exclusively from the waste water produced in household, from not very tight latrines and septic tanks, or from the defecation of the animals raised in the house yards.

Fiala-Foto is the centre town upstream that is not very influenced by the urban activities. But strong concentrations in coliforms and fecal streptococcus were also obtained in this water. The Fiala $b$ stream, coming from Bafou village (out of the urban influence), showed a bacteriological pollution higher than the Fiala $\mathrm{c}$ stream coming from the village Johny Baleng. Bafou is an agricultural zone; the ox herds and other herbivores (sheep and goats) come to water themselves in this water and can defecate on their passage. Water pollution of the sampled wells would be in relation to the physical environment of the latter. These wells whose water is used in watering of crops are localized in the marshy hollows; they are not very deep (less than two meters), and are often located close to the latrines. During the rainy periods, they are often invaded by floodwater.

Under these conditions, it appears that certain cases of gastro-intestinal infections and other water borne diseases, from which the population suffers in Dschang town, are certainly in connection with the consumption of fresh products contaminated by watering water. The presence in this water of high concentrations of bacteria from fecal contamination makes it possible to consider the infections of bacterial origin in enterotoxic Escherichia coli (gastro-enteritises), Salmonella dysenteriesetc, or of parasitic origin. Indeed, in Mexico, most of farmers and their children, working in irrigated fields with untreated sewage effluent, showed a greater prevalence of infection than the general population [22]. The rate of infection decreased with waste processing. The high presence of the indicating bacteria of fecal pollution in irrigation water is discussed in the epidemiologic studies as being associated at the great risk to contract gastro-intestinal and respiratory diseases [22]. The swamps of the Dschang town are exploited in the dry season than in rainy season. For these periods indeed, streams regularly floods through cultivated hollows. Many studies $[16,17,23]$ have showed that the bacteriological level of contamination of water and harvests is higher in the rainy season than in the dry season.

\section{Conclusion}

Through their bacteriological and physico-chemical quality, watering water of crops of the Dschang town does not meet up with the standards of WHO. Certain cases of waterborne diseases which the population suffers in this city are most probably related to the bad quality of watering water of vegetables, and particularly when they are consumed raw. The short-term risks of bacteriological origin are more manifested than those which would be in connection with physico-chemical quality. The swamps are requested especially for the availability of water, and it appears clear that the prohibition of the use of this water would certainly not be the most suitable solution. In order to promote market gardening in Dschang town, taking into account the interest of this activity, a preliminary treatment of the water used for the watering of the crops proves to be necessary. The cultivation crops and produce to be consumed only after cooking could also be an alternative solution. Sensitization of the market-gardeners on the sanitary risks related to the use of wastewater used in agriculture is also to be taken in account.

\section{Acknowledgements}

The authors thank the International Foundation for Science (IFS) for the financial support through the grants $\mathrm{N}^{\circ} \mathrm{W} / 5005-1$ and $\mathrm{N}^{\circ} \mathrm{W} / 4206-2$. Authors also appreciate MM UMARU HASSAN BUBA of the University of Dschang for proofreading this paper.

\section{REFERENCES}

[1] INS, "Annuaire Statistique du Cameroun," Institut National de Statistique, Yaoundé, Cameroun, 2006.

[2] H. Ntangmo Tsafack, E. Temgoua and T. Njine, "Le Maraîchage urbain à Dschang: Exploration des sites de Maraîchage et Identification des Pratiques Culturales," Actes du Colloque Scientifique (CAFOBIOS), Dschang, du 14 au 15 Mai 2009, pp. 49-53.

[3] E. Temgoua, H. Ntangmo Tsafack and T. Njine, "Vegetable Production Systems of Swamps Zone in Urban Environment in West Cameroon: Case of Dschang City," Universal Journal of Environmental Research and Technology, Vol. 2, No. 2, 2012, pp. 83-92.

[4] D. Mara and S. Cairncross, "Guide pour l'Utilisation sans Risques des eaux Résiduaires et des Excréta en Agriculture et Aquaculture," OMS-PNUE, Genève, Suisse, 1991, $202 \mathrm{p}$.

[5] G. Cissé, “Impact Sanitaire de l'Utilisation d'eaux Polluées en Agriculture Urbaine: Cas du Maraîchage à Ouagadougou (Burkina Faso)," Thèse No 1639, Ecole Polytechnique Fédérale de Lausane, Suisse, 1997.

[6] P. Amoah, P. Drechsel, R. Abaidoo and M. Henseler, "Irrigated Urban Vegetable Production in Ghana: Microbiological Contamination in Farms and Markets and Associated Consumer Risk Groups," Journal of Water and Health, Vol. 5, No. 3, 2007, pp. 455-466. 


\section{doi:10.2166/wh.2007.041}

[7] M. L. Ndiaye, S. Niang, H.-R. Pfeifer, R. Peduzzi, M. Tonolla and Y. Dieng, "Effect of Irrigation Water and Processing on the Microbial Quality of Lettuces Produced and Sold on Markets in Dakar (Senegal)," Irrigation and Drain, Vol. 60, No. 4, 2011, pp. 509-517. doi:10.1002/ird.590

[8] M. Gaye and S. Niang, "Epuration Extensive des eaux usées pour leur Réutilisation dans l'Agriculture Urbaine: Des Technologies Appropriées en Zone Sahélienne pour la lutte Contre la Pauvreté," Etudes et Recherches, 225226-227, ENDA, Dakar, 2002, pp. 17-20.

[9] ONU-HABITAT, "Municipalité de Dschang: Une ville au passé Glorieux face aux Nouveaux Défis,” 2005, Résumé $23 \mathrm{p}$.

[10] N. Boon, "Environmental Burden of Water Borne Disease in Dschang, Western Province-Cameroon: Health Impacts and Causal Factors," Breaking Ground Report, 2008, 34 p.

[11] ERA, Cameroun, "Diagnostic de l'Approvisionnement en eau et de l'Assainissement dans la ville de Dschang," CUD, 2005, $107 \mathrm{p}$.

[12] E. Temgoua, E. Ngnikam and B. Ndongson, "Drinking Water Quality: Stakes of Control and Sanitation in the Town of Dschang-Cameroon," International Journal of Biology and Chemical Sciences, Vol. 3, 2009, pp. 441447.

[13] E. Temgoua, "Chemical and Bacteriological Analysis of Drinking Water from Alternative Source in the Dschang Municipality, Cameroon," Journal of Environmental Protection, Vol. 2, No. 5, 2011, pp. 620-628. doi:10.4236/jep.2011.25071

[14] INNORPI, "Institut National de la Normalisation et de la capacité Industrielle de Tunisie. Normes de rejet dans un milieu hydrique," NT, 1989. www.inorpi.ati.tn.r
[15] FAO, "Irrigation avec des eaux usées Traitées, Manuel d'Utilisation," 2003, 73 p.

[16] J. Adouli, C. Abdelkader, C. Abdelhafid and B. Ali, "Suivi et Analyse du Risque lié à l'Utilisation des eaux usées en Agriculture dans la Région de Meknès au Maroc," Sud Sciences et Technologie, Vol. 16, 2008, 29-35.

[17] Z. Derwich, E. Beziane, L. Benaabidate and D. Belghyti, "Evaluation de la Qualité des eaux de Surface des Oueds et Sebou Utilisées en Agriculture au Maroc," Larhyss Journal, Vol. 7, 2008, pp. 59-77.

[18] L. Ndiaye, "Impact Sanitaire des eaux d'Arrosage de l'Agriculture Urbaine de Dakar (Sénégal)," Thèse de Doctorat, Université de Genève, 2009, 166 p.

[19] C. Haslay and H. Leclers, "Microbiologie des eaux d'Alimentation," Technique et document Lavoisier éd., Paris, 1993.

[20] OMS, "L'utilisation des eaux Usées en Agriculture et en Aquaculture: Recommandations à avisées Sanitaires. Organisation Mondiale de la Santé. Série de Rapports Techniques," No 778, OMS, Genève, 1989.

[21] P. Amoah, P. Drechsel and R. Abaidoo, "Irrigated Urban Vegetable Production in Ghana: Sources of Pathogen Contamination and Health Risk Elimination," Irrigation and Drainage, Vol. 54, No. S1, 2005, pp. 49-61. doi:10.1002/ird.185

[22] U.Peasey, M. Blumenthal, ruiz-palacios, "A Review of policy and Standards for Wastewater Reuse in Agriculture a Latin American Perspective," WELL Study, No 68, Part II, 2000. http://www.lboro.ac.uk/well/

[23] M. Nola, "Qualité Bactériologique des eaux Souterraines de Yaoundé: Rôle du sol dans le Transfert à la Nappe Phréatique des Bactério-contaminants de l'eau d'Infiltration," Thèse de Doctorat d'Etat, Univ. Yaoundé 1, Cameroun, 2005, $144 \mathrm{p}$. 